\title{
ENDING BACHA BAZI: BOY SEX SLAVERY AND THE RESPONSIBILITY TO PROTECT DOCTRINE
}

\author{
Samuel V. Jones* \\ "The practice of bacha-bazi, the use of boys as sex slaves \\ by men in positions of power, remained a serious concern.” \\ -Report of the Secretary-General to the United Nations \\ Security Council, May 15, $2014^{1}$
}

\section{INTRODUCTION}

A mother and her twelve-year old son, Nuaman, were forced to leave their town after the death of Nuaman's father. ${ }^{2}$ During their journey, the mother accepted help from men who offered to retrieve a van for the two and drive them safely to their destination. ${ }^{3}$ Instead of transporting the two, Nuaman recalls that the men took him away from his mother and forced him into sexual servitude:

[T]hey kept me in a room for many days in [a place near Peshawar] where first they had sex with me by themselves for many days, and then they allowed everybody else to come and have sex with me for only 40-50 rupees. It was like I was an animal in the zoo, and people could see me and use me after paying the ticket fee. I was twelve and a half years old at that time. Within one month I think 20-30 men had sex with me and I was about to die of it. ${ }^{4}$

The horror Nuaman describes disrupts the lives of potentially thousands of Afghan boys.

Sex trafficking is universally recognized as a heinous crime involving

\footnotetext{
* Professor of Law, The John Marshall Law School, Chicago, Ill. The author sincerely thanks the Indiana International \& Comparative Law Review for inviting him to participate in its symposium. The following essay represents an extended version of the author's presentation at the Indiana University Robert H. McKinney School of Law.

${ }^{1}$ U.N. Secretary-General, Children and Armed Conflict: Rep. of the Secretary-General, I 26, U.N. Doc. A/68/878-S/2014/339 (May 15, 2014).

2 Jan Willem de Lind van Wijngaarden \& Bushra Rani, Male Adolescent Concubinage in Peshawar, Northwestern Pakistan, 13 Culture, Health \& SeXuality 1061, 1064 (2011). Nuaman is a boy from Northwestern Pakistan, an area dominated by the Pashtun ethnic group, which is also known for practicing bacha bazi. Id. at 1061. Hence, the problem is not unique to Afghanistan, though this essay focuses primarily on Afghanistan.

${ }^{3}$ Id. at 1064.

${ }^{4}$ Id.
} 
sexual slavery. ${ }^{5}$ Conventional wisdom is that the sexual enslavement of a child is so unanimously condemned under international law that it garners the highest rebuke. ${ }^{6}$ A government's complicity in the systemic sexual enslavement of its population of children is an abnegation of its sovereign responsibility. ${ }^{7}$ Such action subjects the offending government to sanctions or military intervention under the United Nations' Responsibility to Protect doctrine. $^{8}$

This essay challenges the conventional wisdom that prohibitions against government-condoned child-sex slavery have attained nonderogable, peremptory status under international law. Much to the utter shock of field investigators and human rights experts, boy sex slavery has evolved into a constitutive and central feature of the Islamic Republic of Afghanistan (Afghanistan) because of a customary practice commonly referred to as bacha bazi. ${ }^{9}$

522 U.S.C. § 7101(b)(9) (2012) ("Trafficking includes all the elements of the crime of forcible rape when it involves . . f fraud, force, or coercion.”); Id. § 7101(b)(6) (“Victims are often forced through physical violence to engage in sex acts or perform slavery-like labor. Such force includes rape and other forms of sexual abuse, torture, starvation, imprisonment, threats, psychological abuse, and coercion.”); U.S. DeP’T StATE, TrafFicKing IN PERSONS REPORT 5 (2009), available at http://www.state.gov/documents/organization/123357.pdf ("Victims may suffer physical and emotional abuse, rape, threats against self and family, and even death.”); Samuel V. Jones, Men and Boys and the Ethical Demand for Social Justice, 20 WAsh. \& LEE J. Civil RTs. \& Soc. JusT. 507, 528 (2014) (equating “sex trafficking” to the "systematic rape of boys"); Tanya Mir, Trick or Treat: Why Minors Engaged in Prostitution Should be Treated as Victims, Not Criminals, 51 FAM. CT. REV. 163, 164 (2013) ("Sex trafficking is the only violent crime where the abuser's desire to make money depends on the rape and sexual violence perpetuated against others.”); White House, News Release, President Bush Addresses United Nations General Assembly, (Sept. 23, 2008, 10:12 AM), http://georgewbush-whitehouse.archives.gov/news/releases/2008/09/20080923-5.html (the president stating that nations have a responsibility to protect their populations from "human trafficking and organized crime”).

${ }^{6}$ Melynda H. Barnhart, Sex and Slavery: An Analysis of Three Models of State Human Trafficking Legislation, 16 WM. \& MARY J. WOMEN \& L. 83, 90 (2009) ("Sex trafficking involves forced sex, i.e., rape, and thus constitutes one of the most egregious crimes that humans can inflict upon one another.”).

7 Samuel V. Jones, Human Trafficking Victim Identification: Should Consent Matter?, 45 IND. L. REV. 483, 491 (2012) (explaining that trafficking victims may be "citizens of the very country in which they are relegated to slavery or indentured servitude”).

81 OPPENHEIM’s INT’L LAW $\S 131$, at 442 (Sir Robert Jennings \& Sir Arthur Watts eds., 9th ed. 1996)

(recognizing that there is a "substantial body of opinion and of practice" supporting the view that when a state inflicts cruelties against its people and denies them fundamental human rights, humanitarian intervention may be legally permissible).

${ }^{9}$ See Atia Abawi, Ignored by Society, Afghan Dancing Boys Suffer Centuries-Old Tradition, CNN (Oct. 27, 2009, 1:21 PM), http://www.cnn.com/2009/WORLD/asiapcf/10/26 /ctw.afghanistan.sex.trade/index.html?iref=allsearch (bacha bazi is also referred to as "bacha baazi," "bachabaze," or "boy play," a practice under which Afghan boys are "made to dance and used as sex slaves by powerful men”); Zadzi, Boys in Afghanistan Sold into Prostitution, Sexual 
Legal scholars have largely ignored Afghanistan's bacha bazi tradition, a practice that field observers, U.S. State department officials, and U.S. military officers returning from Afghanistan attribute to creating a culture of male rape. ${ }^{10}$ This academic phenomenology is inextricably driven, in part, by false conceptions about sexual victimization. ${ }^{11}$ Indeed, conceptions about sex slavery, like other sexual victimization crimes, have been myopically formed, promoted, and viewed through news reports, cinema, public awareness programs, academic literature, and criminal statutes as a heinous crime against women and girls. Widespread sensationalized depictions of sexually enslaved women and girls have rendered boy victims practically invisible. ${ }^{12}$ In circumstances where the horror of male sex slavery or rape is undeniable, legal scholars have tended to ignore it, ${ }^{13}$ dismiss it as "rare" or unique to prison populations, ${ }^{14}$ or deem it biologically and psychologically inconsequential given the supposedly elevated social and economic advantage masculinity enjoys over femininity. ${ }^{15}$ But, as this essay will show, such approaches are intellectually corrosive when juxtaposed against the backdrop of Afghanistan's bacha bazi tradition.

Slavery, DigiTAL J. (Nov. 20, 2007), http://digitaljournal.com/article/246409; SHIVANANDA KHAN, NAz Found. InT'L, EverYBody Knows, But NoBOdy Knows, 16, 31 (Sept. 2008), available at http://perma.cc/8BQ8-EBFT; Joel Brinkley, Afghanistan's Dirty Little Secret, SFGATE (Aug. 29, 2010, 4:00 AM), http://www.sfgate.com/opinion/article/Afghanistan-s-dirty-little-secret3176762.php; Pul-E Khumri, Afghan Boy Dancers Sexually Abused by Former Warlords, REUTERS (Nov. 18, 2007, 11:08 PM), http://www.reuters.com/article/2007/11/19/us-afghan-dancingboysidUSISL1848920071119 [hereinafter Former Warlords]; Chris Mondloch, Bacha Bazi: An Afghan Tragedy, FOREIGN POL'Y (Oct. 28, 2013), http://southasia.foreignpolicy.com/posts/2013/10/28 /an_afghan_tragedy_why_rampant_pedophilia_is_a_hurdle_to_peace.

10 See Jim Kouri, Afghan Pedophilia: A Way of Life, Say U.S. Soldiers and Journalists, EXAMINER (Jan. 19, 2012, 3:34 PM), http://www.examiner.com/article/afghan-pedophilia-away-of-life-say-u-s-soldiers-and-journalists (reporting that "Afghanistan is a haven for child rape” according to military officers returning from Afghanistan). A Westlaw search using the term, "bacha bazi," reveals that only five law review publications mention the practice.

11 Samuel V. Jones, The Invisible Women: Have Conceptions About Femininity Led to the Global Dominance of the Female Trafficker?, 7 ALB. Gov'T. L. REv. 143-44, 148-50 (2013) (reasoning that sexual violence and trafficking are almost exclusively examined and interpreted as female victim crimes).

12 Samuel V. Jones, The Invisible Man: The Conscious Neglect of Men and Boys in the War on Human Trafficking, 2010 UTAH L. REV. 1143, 1163-65 (2011) (providing a number of examples in which male victims are routinely omitted from various criminal justice sex crimes statistics, investigations, and prosecutions).

13 Lara Stemple, Male Rape and Human Rights, 60 Hastings L.J. 605, 628-29 (2009) (explaining how some commentators pursue a female-specific approach to rape because of the fear that including male victims will detract from female victimization).

${ }^{14}$ Bennett Capers, Real Rape Too, 99 CAL. L. REV. 1259, 1263-64 (2011).

${ }^{15}$ Mary Ann Franks, How to Feel Like a Woman, or Why Punishment is a Drag, 61 UCLA L. REV. 566, 575-76 (2014) (reasoning that an Afghan bacha bazi boy that is raped and forced to prostitute himself and dress like a girl is better off than an Afghan girl that is forced to dress like a boy in order to obtain an education, even though she is not raped or forced into prostitution). 
Put succinctly, this essay represents a first step in reducing the knowledge gap relative to boy sex slavery that remains so extant in sex trafficking legal discourse. In so doing, Part II discusses the structural dynamics that enable bacha bazi, the perilous existence of boy victims, the Afghan government's unfettered complicity in bacha bazi, the relevant findings of the United Nations Security Council (Security Council), and the threat bacha bazi poses to the preservation of international peace and security. Part III provides an overview of the development and implementation of the Responsibility to Protect doctrine relative to sexual violence. It explains specific features of the United Nations' Responsibility to Protect doctrine that were strategically crafted to omit governmentcondoned boy sexual slavery, such as bacha bazi, from triggering humanitarian based intervention.

\section{BACHA BAZI IN AFGHANISTAN}

Bacha bazi, or "boy for play," involves men known as bacha baz, or "boy players," collectively exploiting, enslaving, or raping young boys in a systematic and organized fashion. ${ }^{16}$ The unabated influence and impunity of wealthy Afghan merchants, illegal armed groups, and government officials drive the demand that propels bacha bazi. Meanwhile, robust poverty, communal nihilism, and a large number of young, vulnerable, and displaced Afghan boys enable its supply. ${ }^{17}$

Boys that become bacha bazi victims are typically destitute and without relatives. ${ }^{18}$ But many extremely poor families, sometimes on the verge of starvation, often sell their sons to bacha baz, ${ }^{19}$ or permit bacha baz to "adopt" their sons in exchange for food, clothing, or money. ${ }^{20}$ Other boys are lured with false promises of a better life via vocational education, responsible supervision, or employment. ${ }^{21}$ Bacha baz, like many traffickers,

\footnotetext{
16 See id.

${ }^{17}$ Afghanistan: An In Depth Look at the Practice of Bacha Bazi (Dancing Boys), CHILD Rights INT'L NETWORK (Sept. 18, 2013), http://www.crin.org/en/library/news-archive/afghanistan-depthlook-practice-bacha-bazi-dancing-boys [hereinafter Bacha Bazi (Dancing with Boys)]; Agenzia Fides, ASIA/AFGHANISTAN - Minors Abducted and Exploited for the Practice of "Bacha Bazi" (Sept. 23, 2013), http://www.fides.org/en/news/34352-ASIA_AFGHANISTAN_Minors_ abducted_and_exploited_for_the_practice_of_Bacha_Bazi\#.UxOr3PRdUpq.

18 John L. CoOK, Afghanistan: The Perfect Failure 95 (2012).

${ }^{19}$ Abawi, supra note 9.

${ }^{20}$ Wijngaarden \& Rani, supra note 2, at 1061; Cook, supra note 18, at 96.

${ }^{21}$ Marcia G. Yerman, “The Dancing Boys of Afghanistan” - Examining Sexual Abuse, DaILy Kos (Feb. 14, 2012, 9:00 PM), http://www.dailykos.com/story/2012/02/15/1064923/--The-DancingBoys-Of-Afghanistan-Examining-Sexual-Abuse; Frontline, The Dancing Boys of Afghanistan, PBS.ORG (Apr. 20, 2010), http://www.pbs.org/wgbh/pages/frontline/dancingboys/etc/synopsis .html.
} 
find boys on the streets, in the marketplace, ${ }^{22}$ or in other public places, such as rest stops where young, hungry boys are known to prostitute themselves. ${ }^{23}$ Many boys are simply abducted. ${ }^{24}$

Bacha bazi boys are typically forced to dress up in female attire, wear bells on their feet, dance for the entertainment of their bacha baz, ${ }^{25}$ or they are rented out for male-only parties where they perform dance routines and are sexually exploited. ${ }^{26}$ If the boys do not dance or perform in a way that pleases observers, the bacha baz beat them. ${ }^{27}$ Once the dancing ends, the boys are generally sold to the highest bidder or shared sexually amongst wealthy or influential Afghan men. ${ }^{28}$ Some men fight over the boys, which sometimes ends in the death of a bacha bazi boy. ${ }^{29}$ For those Afghan men who cannot afford a bacha bazi boy, videos of the boys are typically sold on the streets in major Afghan cities. ${ }^{30}$

The bacha bazi boys' existential identities are inextricably defined by a wide variety of emotional and psychological scars inflicted by their captors, whom they typically despise. ${ }^{31}$ The boys, who know no other life except as chattel, routinely refer to their bacha baz as "my Lord." ${ }^{32}$ Many fear for their lives, hopelessly questioning how they will escape bondage or survive. $^{33}$ They do not report their capture out of fear of stigma, honor killing, or reprisal. ${ }^{34}$ They're told if they escape, their families will be murdered. ${ }^{35}$ A particular brand of sorrow evolves, fueled by a sense of

22 Yerman, supra note 21.

23 InT’L Org. FOR Migration, Trafficking in Persons: An ANALysis of Afghanistan 43-44 (Jan. 2004), available at http://publications.iom.int/bookstore/free/Trafficking_Afghanistan.pdf.

${ }^{24} \mathrm{Id}$. at 37.

25 Sara L. Carlson, To Forgive and Forget: How Reconciliation and Amnesty Legislation in Afghanistan Forgives War Criminals While Forgetting Their Victims, 1 PENN. ST. J.L. \& INT'L AFF. 390, 392 (2012); Cook, supra note 18, at 96; Ghaith Abdul-Ahad, The Dancing Boys of Afghanistan, GuARDIAN (Sept. 11, 2009), http://www.theguardian.com/world/2009/sep/12/dancingboys-afghanistan [hereinafter GuARDIAN, Dancing Boys]; Former Warlords, supra note 11.

26 Ernesto Londoño, Afghanistan Sees Rise in 'Dancing Boys' Exploitation, WASH. Post (Apr. 4, 2012), http://www.washingtonpost.com/world/asia_pacific/afganistans-dancingboys-are-invisible-victims/2012/04/04/gIQAyreSwS_story.html; Frontline, supra note 23.

27 Zadzi, supra note 9.

${ }^{28}$ Kayla Coleman, Bacha Bazi Documentary Uncovers Horrific Sexual Abuse of Afghan Boys, CARE2 (June 19, 2010, 1:30 AM), http://www.care2.com/causes/help-the-dancingboys-of-afghanistan-escape-the-world-of-bacha-bazi.html.

${ }^{29}$ Frontline, supra note 21.

${ }^{30}$ Guardian, Dancing Boys, supra note 25.

31 Ghaith Abdul Ahad, Dancing Boys of Afghanistan, PuB. RADIO InT’L (Sept. 18, 2009, 12:00 AM), http://www.pri.org/stories/2009-09-18/dancing-boys-afghanistan_[hereinafter PRI, Dancing Boys].

${ }^{32}$ Kelly B. Vlahos, The Rape of Afghan Boys, AntiWAr.com (Apr. 13, 2010), http://original.antiwar.com/vlahos/2010/04/12/a-deal-with-the-devil/ [hereinafter Vlahos].

33 See Abawi, supra note 9.

34 See Bacha Bazi (Dancing with Boys), supra note 17.

${ }^{35}$ See id. 
worthlessness and powerlessness, resembling a unique form of depression often seen only in enslaved people. ${ }^{36}$

The boys that survive until the age of nineteen, or until they grow a beard, are typically released from servitude because they no longer possess the prepubertal features bacha baz find appealing. ${ }^{37}$ Ripe with psychological and emotional shame, ${ }^{38}$ and having been denied the opportunity to learn marketable labor skills necessary to support themselves, many bacha bazi boys become bacha baz themselves, often turning to drugs and alcohol as a coping mechanism. ${ }^{39}$ Other boys remain with their captors after becoming men, fully aware of the circumstances under which they first encountered their captors. One Afghan man admitted, "I was only fourteen years-old when a former Uzbek commander forced me to have sex with him. . . . Later, I quit my family and became his secretary. I have been with him for ten [10] years. I am now grown up, but he still loves me and I sleep with him." ${ }^{40}$ Put succinctly, once a boy becomes a victim of bacha bazi, he is typically deranged and emotionally traumatized for life.

\section{A. The Subordinated Status of Afghan Women Contributes to Bacha Bazi}

Most Afghan men that keep bacha bazi boys have wives. ${ }^{41}$ Reportedly, a popular Afghan adage is that "women are for children, boys are for pleasure." ${ }^{42}$ Such sentiments help explain why in some parts of Afghanistan, such as Kandahar, a city heralded for its "beardless boys" 43 and high instances of bachi bazi, women are largely subordinated and banned from participating in many aspects of public life. ${ }^{44} \mathrm{~A}$ woman that has sex outside of marriage can be put to death, along with her partner.

\footnotetext{
${ }^{36}$ See Abawi, supra note 9; see also Jones, supra note 12, at 1151 (“As with most victims of sex trafficking, such acts wreak havoc on the child's physical, psychological, and social well-being, resulting in headaches, stomach aches, eating disorders, fear, anxiety, depression, declining grades, aggression, and increased likelihood of adolescent prostitution, substance abuse, and suicide attempts.”).

37 Guardian, Dancing Boys, supra note 25; Cook, supra note 18, at 97; see Claude d'Estrée, Voices from Victims and Survivors of Human Trafficking, in Human TrafFICKING: EXPLORING THE INTERNATIONAL NATURE, CONCERNS, AND COMPLEXITIES 79, 94 (John Winterdyk, Benjamin Perrin \& Philip Reichel, eds., 2012) (suggesting that some of the victimized boys are so young, they are almost "genderless” to their captors).

${ }^{38}$ Abawi, supra note 9.

${ }^{39}$ Londoño, supra note 25; Abawi, supra note 9.

${ }^{40}$ Former Warlords, supra note 9.

${ }^{41}$ Bacha Bazi (Dancing with Boys), supra note 17.

42 U.S. Army, Human Terrain Team (HTT) AF-6, Research Update and Findings: Pashtun SeXuality 9 (2010) [hereinafter Pashtun SeXuality], available at http:// www.scribd.com/doc/39111225/Pashtun-Sexuality; Cook, supra note 19, at 96.

${ }^{43}$ Pashtun SeXuality, supra note 4, at 10.

${ }^{44}$ See id. at 2; see also Former Warlords, supra note 9.
} 
While, conversely, men routinely have sex with bacha bazi boys and force the boys to accompany them on public errands, at parties, and even to their homes, effectually undermining and subordinating the Afghan wife or mother. ${ }^{45}$ When an Afghan man, who kept a young boy, was asked what the boy's family thought, he merely shrugged and countered that it was not an issue "because the boy's father had died," showing no concern for the feelings or rights of the child's mother. ${ }^{46}$ Another Afghan man reported:

I was married to a woman 20 years ago, she left me because of my boy. ... I I was playing with my boy every night and was away from home, eventually my wife decided to leave me. I am happy with my decision because I am used to sleeping and entertaining with my young boy. ${ }^{47}$

Put succinctly, bacha bazi not only enslaves Afghan children, it relegates Afghan women, namely mothers and wives, to a grim and subordinated state of existence.

In most parts of the world, the sexual exploitation or enslavement of a child would be considered repugnant, morally objectionable, and criminal. But in Afghanistan, enslaving and sexually exploiting a boy is no more disparaging and injurious to an Afghan man's reputation than was having a slave in the Antebellum South. Like the Antebellum South slave master, enslaving an Afghan boy appears to enhance an Afghan man's financial status and reputation. The more physically appealing and talented the bacha bazi boy is perceived to be, the more he enriches his captor's social and financial standing. ${ }^{48}$ As one Afghan woman explained, "[h]aving a boy has become a custom for us. Whoever wants to show off, should have a boy." 49 For that reason, Afghan men openly flaunt their bacha bazi boys.

Contention exists regarding the legitimacy of bacha bazi under Islamic law. Many Afghans strongly object to bacha bazi on grounds that it is homosexual in nature, and banned by Islamic tradition. ${ }^{50}$ Some Afghan

45 See Afghan Men Struggle with Sexual Identity, Study Finds, FoxNews.COM (Jan. 28, 2010), http://www.foxnews.com/politics/2010/01/28/afghan-men-struggle-sexual-identitystudy-finds/; see also Wijngaarden \& Rani, supra note 2.

${ }^{46}$ Ernest Londoño, Afghanistan's 'Dancing Boys': Behind the Story, WAsh. Post (Apr. 5, 2012, 9:47 AM), http://www.washingtonpost.com/blogs/blogpost/post/afghanistans-dancingboys-behind-the-story/2012/04/05/gIQAFXzJxS_blog.html [hereinafter Londoño, Behind the Story].

${ }^{47}$ Vlahos, supra note 32.

${ }^{48}$ Pashtun SeXuality, supra note 42, at 10.

${ }^{49}$ Former Warlords, supra note 9.

50 See Zadzi, supra note 9; see also Press Release, U.N. Dep’t of Pub. Info., Urgent Action Needed by World Community to Stamp Out Violence Against Children, Newly Appointed Special Representative Tells Third Committee, GA/SHC/3951 (Oct. 14, 2009), http://www.un.org/ 
men assert that Islam only prohibits a man from loving another man, but does not prohibit a man from using a boy for sex. ${ }^{51}$ In addition, some Afghan men engage in bacha bazi, despite being convinced that Islamic law prohibits their behavior. Chaman Gul, an Afghan man, conceded: "We know it is immoral and unIslamic, but how can we quit? We do not like women, we just want boys." 52

\section{B. The Afghan Government Condones Bacha Bazi}

Regardless of whether Islamic law prohibits bacha bazi, United Nations officials and human rights organizations widely view it as an unacceptable form of child sexual servitude. ${ }^{53}$ But unlike many forms of organized child sexual slavery, bacha bazi flourishes, unabated, with seemingly tacit approval of the Afghan government despite its contrary treaty obligations. ${ }^{54}$

The Security Council has flatly condemned the deplorable circumstances affecting Afghan children and urged the Afghan government "to take immediate and specific measures to put an end to and prevent the perpetration of . . . bacha bazi." 55 The United Nations published a detailed manual tailored to help the Afghanistan government implement a legal framework for banning child sex trafficking. ${ }^{56}$ The Afghan government also

News/Press/docs/2009/gashc3951.doc.htm; see also U.N. News Centre, Afghanistan: UN Official Urges Steps to Prevent Child Deaths in Conflict (Feb. 24, 2010), http://www.un.org/ apps/news/printnewsAr.asp?nid=33879\&Cr=afghan\&Cr1\#.UI1PldWGd.

${ }^{51}$ Id.

${ }^{52}$ Former Warlords, supra note 9.

53 Aazem Arash, AIHRC Turns Toward Stemming Bacha Bazi, TOLONEws (Oct. 30, 2013, 6:27 PM), http://www.tolonews.com/en/afghanistan/12435-aihrc-turns-toward-stemmingbacha-bazi.

54 See Londoño, supra note 26 (referring to the practice as being an "open secret in Afghanistan, [that] is seldom discussed in public or with outsiders”); see also PRI, Dancing Boys, supra note 31 (claiming that the roots of bacha bazi date back thousands of years).

${ }_{55}$ Press Release, U.N. Dep’t of Pub. Info., Statement by Chairman of Security Council Working Group on Children and Armed Conflict, SC/10259-/AF/G369-HR/5054 (May 18, 2011), http://www.un.org/News/Press/docs/2011/sc10259.doc.htm ("Also urging them to take immediate and specific measures to put an end to and prevent the perpetration of sexual violence by members of their respective groups, in particular the practice of bacha b[]azi, to take measures so that perpetrators are brought to justice and to publicly declare an end to such practice.”).

${ }^{56}$ U.N. Office on Drugs and Crime, Appropriate Legal Responses to Combating Trafficking in Persons in Afghanistan: Manual for Parliamentarians of Afghanistan (July 2008), available at http://www.unodc.org/documents/human-trafficking/Legal_Responses_to_ Trafficking_in_Persons_Manual_for_Parliamentarians_of_Afghanistan.pdf. The U.N. effort to assist Afghanistan with the legal response manual is consistent with its concern that "a global deficiency in knowledge about human trafficking” existed and that many countries needed to engage in "more extensive research, intelligence gathering, and information sharing.” See Jones, supra note 11, at 145. 
signed the Convention on the Rights of the Child ${ }^{57}$ and acceded to the Protocol to the Convention on the Rights of the Child on the Sale of Children, Child Prostitution and Child Pornography. ${ }^{58}$ Still, the Afghan government has failed to implement an effective system of justice designed to enforce these treaty obligations and prohibit the rape of male children. ${ }^{59}$ Upon receiving news that bacha bazi represented a grave breach of its human rights obligations, Afghan President Hamid Karzai dismissed the idea of instituting immediate measures to protect Afghan's boys from sexual servitude, and replied, "[l]et us win the war first. Then we will deal with such matters."60

Not only is the Afghan government known to prosecute boy victims of bacha bazi, rather than the adult male victimizers, ${ }^{61}$ but state officials sexually exploit young boys with alarming impunity. ${ }^{62}$ Some Afghan provincial governors are known to openly keep bacha bazi harems. ${ }^{63}$ Afghanistan's military and police officials are some of the most vigorous sexual predators ${ }^{64}$ and make no effort to conceal their sexual exploitation of

\footnotetext{
${ }^{57}$ See Convention on the Rights of the Child, opened for signature Nov. 20, 1989, 1577 U.N.T.S. 3 (entered into force Sept. 2, 1990), available at http://www.ohchr.org/ en/professionalinterest/ pages/crc.aspx.

${ }^{58}$ Optional Protocol to the Convention on the Rights of the Child on the Sale of Children, Child Prostitution and Child Pornography, opened for signature May 25, 2000, 2171 U.N.T.S. 227 (entered into force Jan. 18, 2002), available at https://treaties.un.org/pages/viewdetails.aspx? src=ind\&mtdsg_no=iv-11-c\&chapter=4\&lang=en.

${ }^{59}$ Afghanistan: Don't Prosecute Sexually Assaulted Children, Human Rights Watch (Feb. 10, 2013), http://www.hrw.org/news/2013/02/09/afghanistan-don-t-prosecute-sexuallyassaulted-children (reporting that the Afghan Penal Code "refers only to the rape of women or girls" and that "[t]here is no comparable specific prohibition on rape of men and boys"); see Kouri, supra note 9; see also Amitai Etzioni, Stop Enabling Pedophilia, WorLd Post (Jan. 4, 2012, 10:50 AM), http://www.huffingtonpost.com/amitai-etzioni/stop-enablingpedophilia_b_1183408.html; see also Afghanistan: UN Urges More Action on Child Rights, IRIN NEws (Feb. 9, 2011), http://www.irinnews.org/report/91869/afghanistan-un-urgesmore-action-on-child-rights (explaining that the prevention of bacha bazi in Afghanistan is difficult because of "problems with the judiciary and the justice system").

${ }^{60}$ Yerman, Dancing Boys, supra 21.

${ }^{61}$ Fides, supra note 17; Abawi, supra note 9.

${ }^{62}$ Fides, supra note 17; Zadzi, supra note 9.

63 Rod Nordland, Deadly Betrayals, and Unsettling Patterns; in Latest Attacks, Officers Are Being Killed by Fellow Afghans While They Sleep, InT'L Herald TriBune (Dec. 29, 2012) at 3.

${ }^{64}$ Cook, supra note 18, at 96; Human Rights Watch, Afghanistan: “Just Don'T Call it A Militia”: Impunity, Militias, And the “Afghan Local Police” 48-49 (Sept. 2011), available at http://www.hrw.org/sites/default/files/reports/afghanistan0911webwcover.pdf; Press Release, U.N. Dep’t of Pub. Info.; Press Conference to Launch Report 'Setting the Right Priorities: Protecting Children Affected by Armed Conflict in Afghanistan,' (June 14, 2010), http://www.un.org/News/briefings/docs/2010/100614_Children.doc.htm.
} 
Afghan's boy population. ${ }^{65}$ Numerous Afghan boys are detained and sexually assaulted in government facilities without charges or an opportunity to have the legality of their imprisonment reviewed by a court. ${ }^{66}$

Frontline's documentary, The Dancing Boys of Afghanistan, presented video footage of Afghan police officers openly fondling young Afghan boys. ${ }^{67}$ An Afghan Thursday night tradition involves uniformed Afghan police officers lining up several pre-teen boys and taking a select few into the police station for hours at a time. ${ }^{68}$ The discoveries reported in the documentary not only comport with findings made by the Security Council, but also validate reports by the U.S. State Department, which found that the Afghan government has failed to make "discernible progress in protecting victims of trafficking" and its officials systematically engage in the "sexual abuse of boys." 69 In May 2014, the U.N. Secretary-General officially designated the Afghan National Police and Local Police as "parties" that engage "in the recruitment and use of children, sexual violence against children, the killing and maiming of children, recurrent attacks on schools and/or hospitals and recurrent attacks or threats of attacks against protected personnel in contravention of international law."70

Because of bacha bazi's resurgence after being banned by the Taliban, and the Afghan government's complicity in the practice, obtaining an accurate count of child victims of bacha bazi is virtually impossible. ${ }^{71}$ But at least one observer has noted that approximately "half the Pashtun tribal members in Kandahar and other southern towns are bacha baz."72 Observers claim that at least one out of every five Afghan weddings include bacha bazi. ${ }^{73}$

Bacha bazi so freely permeates Afghanistan that it now threatens the legitimacy and authority of the Afghan government. The woeful reality of the Afghan government's complicity in bacha bazi and absence of an effective legal infrastructure to halt its growth has left scores of Afghans with a seething outrage and deep-rooted doubt regarding the international

65 Don Martin, Afghan Justice Clashes with Our Version of the Law, CALGARY HerALD (June 17, 2008), http://www.canada.com/calgaryherald/columnists/story.html?id=76262860cde1-40b3-b6dd-a17cbe6dee8f.

${ }^{66}$ Children in Armed Conflict Report, supra note 1, at 924.

${ }^{67}$ Frontline, supra note 21; Coleman, supra note 28.

${ }^{68}$ Frontline, supra note 21.

69 U.S. DeP'T of State, Trafficking in PERsons RePORT 62-63 (2012), available at http://www.state.gov/j/tip/rls/tiprpt/2012/.

${ }^{70}$ Children in Armed Conflict Report, supra note 1, \ 3.

${ }^{71}$ Country Profile: Afghanistan, CARTER CTR., http://www.cartercenter.org/peace/human_rights/ defenders/countries/afghanistan.html (last updated Nov. 2009); Londoño, supra note 27; Cook, supra note 20, at 97 .

72 Brinkley, supra note 9.

${ }^{73}$ Londoño, supra note 26. 
community's resolve to do justice. The festering sore of oppression and government corruption is so heightened that many Afghan citizens now prefer Taliban rule. ${ }^{74}$ Many insurgents continue to fight in Afghanistan because they view the Taliban as the only viable alternative to the existing government, which they deem too corrupt to provide "basic needs such as long term employment, schools, hospitals and a justice system.”75

The Afghan government's failure to safeguard its populace from sexual violence has significantly undermined U.S. counterinsurgency objectives, raising serious questions about prospects for peace and security in the region. ${ }^{76}$ There is no question that the success of U.S. counterinsurgency policy relies principally on the protection of the Afghan populace. In 2009, the U.S. announced that the safeguarding of Afghan citizens would even take precedence over attempts to kill the Taliban. ${ }^{77}$ The perilous reality of systemic child sex trafficking in Afghanistan has reduced prospects for peace and security, prompting serious questions as to whether the international community has an obligation to intervene on behalf of the victims under the Responsibility to Protect doctrine.

\section{THE RESPONSIBILITY TO PROTECT DOCTRINE DOES NOT PROTECT ENDANGERED POPULATIONS FROM CHILD SEX TRAFFICKING}

As a member state of the United Nations, the Afghan government is obligated to respect international human rights. ${ }^{78}$ The U.N. Charter bars

\footnotetext{
${ }^{74}$ Patrick Cockburn, Stealing Money, Selling Heroin and Raping Boys -- The Very Dark Side of the Afghan Occupation, ALTERNET (Nov. 13, 2009), http://www.alternet.org/story/143956/stealing _money\%2C_selling_heroin_and_raping_boys_--_the_very_dark_side_of_the_afghan_ occupation.

${ }^{75}$ Mark E. Johnson, Reintegration and Reconciliation in Afghanistan: Time to End the Conflict, Mil. REv. Nov. - Dec. 2010, at 97, 97, available at http://usacac.army.mil/CAC2/MilitaryReview/Archives/English/MilitaryReview_20101231_ art016.pdf.

76 Samuel V. Jones, The Ethics of Letting Civilians Die in Afghanistan: The False Dichotomy Between Hobbesian and Kantian Rescue Paradigms, 59 DePAul L. Rev. 899, 901-02 (2010) [hereinafter Jones, Afghanistan] (explaining that the success of U.S. counterinsurgency operations in Afghanistan is contingent upon protecting the civilian populace in order to deprive the Taliban of its power and appeal); Kevin T. Carroll, Afghan Corruption - the Greatest Obstacle to Victory in Operation Enduring Freedom, 43 GEO J. OF INT’L LAW 873 (2012) (“If we don't get a level of legitimacy and governance, then all the troops in the world aren't going to make any difference. ... Karzai has got to take concrete steps to eliminate corruption. That means that you have to rid yourself of those who are corrupt, you have to actually arrest and prosecute them.”); Azam Ahmed, Taliban Making Military Gains in Afghanistan, N.Y. TIMES, July 26, 2014, http://www.nytimes.com/2014/07/27/world/asia/taliban-making-military-gains-in-

afghanistan.html?hp\&action=click\&pgtype=Homepage\&version=HpSum\&module=first-columnregion\&region=top-news\&WT.nav=top-news.

77 Jones, Afghanistan, supra note 76, at 902.

${ }^{78}$ See United Nations, Member States of the United Nations, http://www.un.org/en/members/; M. Cherif Bassiouni, The Perennial Conflict Between International Criminal Justice and Realpolitik,
} 
member states from intervening in the internal affairs of another member state, unless in self-defense. ${ }^{79}$ Despite the purportedly non-derogable, jus cogens status of international prohibitions against slavery and rape, ${ }^{80}$ and the well-documented episodes of sexual violence that occurred in Rwanda and Kosovo, the United Nations has not adopted a legal framework by which member states can appropriately intervene in distressed nations, such as Afghanistan, to prevent systemic child sex trafficking.

22 GA. St. U. L. REV. 541, 542 (2006) (“In the last 50 years, national legal systems have qualitatively advanced far more than during the preceding 7,000 years. This advance is largely due to the impact of international human rights norms on national legislation. ... [T] o some extent, this permeation of international human rights norms and standards has also occurred in the international legal system.”); Article 1(3) of the U.N. Charter states that among the UN's purposes is to "achieve international co-operation . . . in promoting and encouraging respect for human rights and for fundamental freedom for all.” U.N. Charter art. 1, para. 3. Additionally, Articles 55 and 56 of the U.N. Charter provide that all member states "pledge themselves to take joint and separate action in co-operation with the Organization for the achievement of . . . universal respect for, and observance of, human rights.” U.N. Charter art. 55(c), 56.

${ }^{79}$ U.N. Charter art. 2, para. 7 ("Nothing contained in the present Charter shall authorize the United Nations to intervene in matters which are essentially within the domestic jurisdiction of any state ... ; but this principle shall not prejudice the application of enforcement measures under Chapter VII.”); U.N. Charter art. 2, para. 4 (“All Members shall refrain in their international relations from the threat or use of force against the territorial integrity or political independence of any state, or in any other manner inconsistent with the Purposes of the United Nations.”); G.A. Res. 2625 (XXV), U.N. Doc. A/1889 (Oct. 24, 1970); U.N. Charter art. 51 ("Nothing in the present Charter shall impair the inherent right of individual or collective self-defense if an armed attack occurs against a Member of the United Nations, until the Security Council has taken measures necessary to maintain international peace and security. Measures taken by Members in the exercise of this right of self-defense shall be immediately reported to the Security Council and shall not in any way affect the authority and responsibility of the Security Council under the present Charter to take at any time such action as it deems necessary in order to maintain or restore international peace and security.”).

80 Jack Alan Levy, As Between Princz and King: Reassessing the Law of Foreign Sovereign Immunity as Applied to Jus Cogens Violators, 86 GEO. L.J. 2703, 2706-07 (1998) (recognizing that the corpus of jus cogens humanum evolves over time because of the discovery and recognition of additional norms); United States v. Matta-Ballesteros, 71 F.3d 754, 764 (9th Cir. 1995); Felice D. Gaer, Rape As a Form of Torture: The Experience of the Committee Against Torture, 15 CUNY L. REV. 293, 307 (2012) (“[R]ape . . . will remain as one of the gravest human rights violations having peremptory or jus cogens status.”); David S. Mitchell, The Prohibition of Rape in International Humanitarian Law as a Norm of Jus Cogens: Clarifying the Doctrine, 15 DukE J. ComP. \& INT’L L. 219, 234 (2005) (“The jus cogens nature of a norm barring rape under international humanitarian law is evident in a number of sources.”); Pamela J. Stephens, A Categorical Approach to Human Rights Claims: Jus Cogens As a Limitation on Enforcement, 22 WIS. INT'L L.J. 245, 259 (2004) (citing various cases for the proposition that slavery, rape and torture are jus cogens violations of international law); A.P.V. Rogers, Humanitarian Intervention and International Law, 27 HARV. J.L. \& PUB. POL'Y 725, 733-734 (2004) (reasoning that a recent trend in international practice has been to deviate from the long-accepted practice of noninterference when serious human rights violations have occurred); ALLEN BuCHANAN, Justice, LEGITIMACY, AND SELF DETERMINATION, 225 (2004). 
When the International Commission on Intervention and State Sovereignty (ICISS) ${ }^{81}$ considered whether member states should have a right to intervene, it proposed that the well-established principle of nonintervention should yield to the international responsibility to protect endangered populations in "situations of compelling human need," via "sanctions," "prosecution," and "in extreme cases, military intervention." 82 ICISS developed the Responsibility to Protect doctrine based on its recognition that member states have an obligation to protect their citizens from "mass murder," "rape," and "starvation." When member states are "unwilling or unable" to meet these commitments, "that responsibility must be borne by the broader community of states." ${ }^{33}$ In an apparent effort to exclude child sex slavery practices, like bacha bazi, ICISS proposed that intervention would only be justified in circumstances where the rape committed involved "systematic rape for political purposes of women of a particular group either as another form of terrorism, or as a means of changing the ethnic composition of that group." ${ }^{84}$ ICISS emphasized that its goal was "to focus on protecting communities from mass killing," and "women" rather than boys "from systematic rape," and "children from starvation." ${ }^{85}$ ICISS made no attempt to acknowledge sexual violence against children, choosing instead to suggest that rape affects only women.

When the United Nations hosted the 2005 World Summit, global leaders articulated their conclusions regarding the Responsibility to Protect doctrine in the 2005 World Summit Outcome Document (Summit Outcome) ${ }^{86}$ Consistent with ICISS, the Summit Outcome recognized the

81 Int'l Comm'n on Intervention and State Sovereignty [ICISS], The Responsibility to Protect: Report of the International Commission on Intervention and State Sovereignty, at 1 (Dec. 2001), available at http://responsibilitytoprotect.org/ICISS\%20Report.pdf at 2 [hereinafter ICISS REPORT]; Paul R. Williams, J. Trevor Ulbrick \& Jonathan Worboys, Preventing Mass Atrocity Crimes: The Responsibility to Protect and the Syria Crisis, 45 CASE W. RES. J. INT'L L. 473, 477 (2012); see generally Scott Woodward, The Responsibility to Protect: The Time is Now, 23 MediterRanean Q. 82 (Summer 2012).

82 ICISS REPORT, supra note 81, at XII. (where military intervention is contemplated, ICISS proposed that the legitimacy of the intervention be conditioned upon: (1) there being a just cause, such as a "large scale loss of life" or "large scale "ethnic cleansing"”; (2) the assistance is a true last resort as other peaceful options have been explored and exhausted; (3) "rightful intention" on the part of the intervening state; (4) the action is proportional to the humanitarian crisis; (5) that action has a reasonable chance of success; and (6) the action is authorized by a legitimate authority, like the Security Council). See id. at XII.

${ }^{83} \mathrm{Id}$. at VIII.

${ }^{84} \mathrm{Id}$. at 33.

85 Id. at 17.

862005 World Summit Outcome, G.A. Res. 60/1, U.N. Doc. A/RES/60/1, at 30 (Oct. 24, 2005), available at http://daccess-dds-ny.un.org/doc/UNDOC/GEN/N05/487/60/PDF/N0548760.pdf? OpenElement; The World Summit: 'A Moving Force', UN CHRON., 42, no. 4:6 (Dec. 2005); see also S.C. Res. 1674, U.N. Doc. S/RES/1674 (Apr. 28, 2009) (confirming the responsibility to 
applicability of the Responsibility to Protect doctrine when a nation fails to protect its citizens from human rights atrocities after peaceful means have proven unsuccessful. ${ }^{87}$ However, by expressing a desire that governments protect their child citizens from "sexual abuse and exploitation and trafficking," the Summit Outcome departed drastically from the limitations ICISS proposed regarding sexual violence. ${ }^{88}$ The recommendation appeared to be a clear attempt to protect children from sex trafficking practices, like bacha bazi.

Following the 2005 World Summit, the U.N. Security Council issued Resolution 1820, setting forth its position regarding sexual violence. ${ }^{89}$ The Security Council appeared to distort the concerns expressed in the Summit Outcome by qualifying the document's "resolve" as one principally dedicated to protecting "women and girls" rather than "children." ${ }^{90}$ Among other things, the Security Council: (1) reiterated its desire to protect "civilians, in particular women and girls;" (2) noted that "women and girls are particularly targeted by the use of sexual violence;" (3) reminded member states of their obligation "to ensure that all victims of sexual violence, particularly women and girls, have equal protection under the law and equal access to justice;" and (4) demanded that member states exercise appropriate measures against "parties to situations of armed conflict who commit rape and other forms of sexual violence against women and girls." 91 The U.N. Security Council made no reference to men and boys. Instead, through the use of strategic legalism and gender-specific language, it endorsed the false supposition that sexual violence is only a male culpritfemale victim occurrence. Perhaps more surprisingly, the U.N. Security Council completely omitted any reference to the Summit Outcome's recommendation that governments take appropriate actions to protect children from "sexual abuse and exploitation and trafficking." 92 In effect, U.N. Security Council Resolution 1820 repudiated any claim that child

protect civilian populations from human rights atrocities, as provided in paragraphs 138 and 139 of the 2005 World Summit Outcome Document).

872005 World Summit Outcome, supra note 86, at 139 (“The international community, through the United Nations, also has the responsibility . . . to help to protect populations from genocide, war crimes, ethnic cleansing and crimes against humanity. . . . [W]e are prepared to take collective action, in a timely and decisive manner, through the Security Council ... on a case-by-case basis and in cooperation with relevant regional organizations as appropriate, should peaceful means be inadequate and national authorities are manifestly failing to protect their populations.”).

${ }^{88} \mathrm{Id}$. at 141.

89 S.C. Res. 1325, U.N. Doc. S/RES/1820 (June 19, 2008).

90 Id. ("Reaffirming also the resolve expressed in the 2005 World Summit Outcome Document to eliminate all forms of violence against women and girls, including by ending impunity and by ensuring the protection of civilians, in particular women and girls, during and after armed conflicts, in accordance with the obligations States have undertaken under international humanitarian law and international human rights law.”).

${ }^{91}$ See Id.

922005 World Summit Outcome, supra note 86, at $\uparrow 141$. 
sexual exploitation and trafficking triggered a right of intervention. Instead, the U.N. Security Council declared that sexual violence, "when used as a tactic of war against civilians, can significantly exacerbate situations of armed conflict and impede the restoration of international peace and security." ${ }^{93}$ By adopting the formulaic standards ICISS proposed, and excluding exploitation and trafficking, the U.N. Security Council declared its position that sexual exploitation and trafficking did not represent a sufficient or credible threat to the restoration of international peace and security.

In 2009, the U.N. codified the Responsibility to Protect doctrine. ${ }^{94} \mathrm{It}$ formally declared that when a state refuses to accept assistance, fails to protect its population, and ignores less coercive measures, then intervention could be authorized by the Security Council, ${ }^{95}$ the General Assembly under the "Uniting for Peace" procedure, ${ }^{96}$ or via regional or sub-regional agreements with the prior authorization of the Security Council. ${ }^{97}$ In cases where mass sexual violence endangers a population and its government is either unwilling or unable to stop it, the U.N. suggested that intervention under the Responsibility to Protect doctrine would be appropriate only under the criteria specifically enunciated in Security Council Resolution 1820. ${ }^{98}$ The resolution excluded child sexual exploitation and trafficking, such as bacha bazi, from triggering international intervention.

\section{CONCLUSION}

Over a decade ago, then U.N. Secretary-General Kofi Annan warned that in countries throughout the world, including Afghanistan, "there are a great number of people who need more than just words of sympathy from the international community. They need a real and sustained commitment to help end their cycles of violence." 99 Since his remarks, the level of sexual

${ }^{93}$ UNSC/S/RES/1820, (June 19, 2008).

94 Implementing the Responsibility to Protect, G.A. Res. 63/677, ๆ 67, U.N. Doc. A/RES/63/677 (Jan. 12, 2009), available at http://www.un.org/ga/search/view_doc.asp?symbol=A/63/677 [hereinafter Implementing R2P].

${ }^{95} I d$. at 925 , para 56 (relying on “Articles 41 or 42 of the Charter”).

96 Id.; see also, Samuel V. Jones, Darfur, The Authority of Law, and International Humanitarian Intervention, 39 U. ToL. L. REV. 97, 115 (2007) (asserting that the General Assembly may authorize humanitarian intervention pursuant to the "United for Peace Resolution" because it was "specifically designed to create a decision-making role for the General Assembly in situations when, as with the crisis in Sudan, the UNSC becomes paralyzed by veto or bias and fails to discharge its responsibilities”).

${ }^{97}$ Implementing R2P, supra note 94, at 925 , para 56.

${ }^{98} \mathrm{Id}$. at I 25, para 57 (stating that "in the case of sexual violence [sanctions would be triggered] in accordance with the terms contained in Council resolution 1820 (2008)”).

99 Kofi Annan, Secretary-General Address to the United Nations General Assembly (Sept. 20, 1999), UNIS.SG.2381, available at http://www.unis.unvienna.org/unis/en/pressrels/1999/ sg2381.html. 
violence perpetrated against Afghan's boy population has persisted with alarming regularity.

The undeniable consequence of the lack of international protection of bacha bazi victims is that Afghan officials feel no genuine obligation to comply with treaty obligations that require them to respect the human rights of its boy population. The lack of humanitarian intervention suggests that there is no genuine demand that the Afghan government install an effective judiciary, justice system, and police force, to protect its population of boys from sexual exploitation and trafficking, prosecute offenders and prevent bacha bazi. Without a credible legal demand or threat of coercive action, there is virtually no incentive for the Afghan government to limit its actions or curtail the range of atrocities currently being inflicted upon the powerless and hopeless boys of Afghanistan. The United Nations' unwillingness to adopt a framework that triggers a right to intervene in response to the Afghan government's obvious complicity in bacha bazi, makes the United Nations an ideological accomplice to its practice, which, unequivocally, now represents a clear threat to international peace and security in the region. 